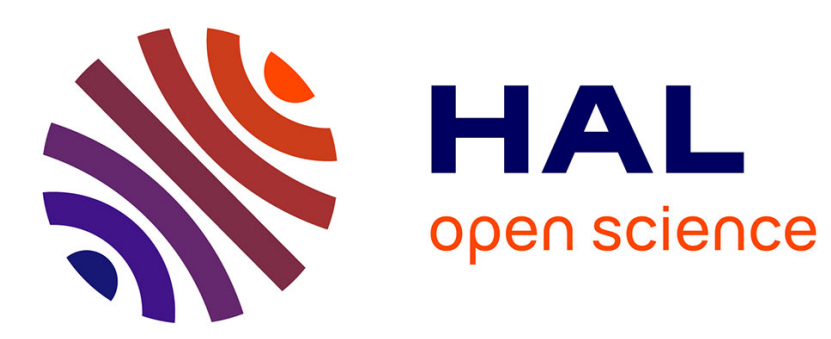

\title{
Fourier transform infrared photoacoustic spectroscopy to study the penetration of substances through skin
}

M. Baesso, R. Snook, J. Andrew

\section{To cite this version:}

M. Baesso, R. Snook, J. Andrew. Fourier transform infrared photoacoustic spectroscopy to study the penetration of substances through skin. Journal de Physique IV Proceedings, 1994, 04 (C7), pp.C7-449-C7-451. 10.1051/jp4:19947104 . jpa-00253156

\section{HAL Id: jpa-00253156 https://hal.science/jpa-00253156}

Submitted on 1 Jan 1994

HAL is a multi-disciplinary open access archive for the deposit and dissemination of scientific research documents, whether they are published or not. The documents may come from teaching and research institutions in France or abroad, or from public or private research centers.
L'archive ouverte pluridisciplinaire HAL, est destinée au dépôt et à la diffusion de documents scientifiques de niveau recherche, publiés ou non, émanant des établissements d'enseignement et de recherche français ou étrangers, des laboratoires publics ou privés. 


\title{
Fourier transform infrared photoacoustic spectroscopy to study the penetration of substances through skin
}

\author{
M.L. Baesso, R.D. Snook and J.J. Andrew* \\ DIAS, UMIST, M60 IQD, Manchester, U.K. \\ * Unilever Research, Port Sunlight Laboratory, L63 3JW, Bebington, U.K.
}

\begin{abstract}
Step-scan Fourier Transform Infrared (FT-IR) Photoacoustic Spectroscopy(PAS) has been used to study the penetration of substances through abdominal pig skin. The experiments were performed in vitro and dimethylsulfoxide(DMSO) was applied either onto the surface or the bottom of the sample. The results demonstrated that DMSO propagated fast through the skin from the bottom surface. The ease of identification of this substance in this spectral range showed the potential of the technique, suggesting that penetration and distribution of other chemicals through the skin can be investigated by FT-IR PAS.
\end{abstract}

\section{INTRODUCTION}

Penetration and interaction of substances through skin have been investigated both for medical and cosmetic purposes, but the mechanism involved is not well understood[1,2]. Based on its ability to perform depth profile analysis, PAS has already been shown to be suitable for the study of penetration of topically applied substances into skin[3-5]. Giese et al, for example, have studied the penetration of sunscreen into human skin, in the visible spectral range[5].

The absorption bands from specific group components of substances are easily identified in the infrared spectral range, and a technique such as photoacoustic spectroscopy, which provides depth profile analysis in this range, may be convenient to study the distribution of substances through the skin.

PAS provides depth profile analysis by measuring the spectra at different modulation frequency or by phase resolved measurements. Here, $\mu\left(\mu=(\alpha /(\pi \mathrm{f}))^{1 / 2}\right)$ is the sample thermal diffusion length, $\alpha$ is the sample thermal diffusivity and $\mathrm{f}$ the light modulation frequency. For phase resolved measurements, the PA signal phase lag between the surface and subsurface layers, (for samples composed of layers), and between absorbers, (for samples comprising absorbers with different non radiative relaxation time), permits the separation of those components[6,7]. This method has been shown to be more accurate than the frequency modulation variation[7].

The recent application of step scan interferometry to PAS in the infrared allowed phase resolved measurements to be performed in this spectral range. This method has been used successfully to study depth profiles in polymer coatings[7]. In the step scan FT-IR, the PA signal is obtained at a constant frequency over the whole spectral range, and therefore the thermal diffusion length is constant for all wavelengths, different from FT-IR PAS continuous scan mode, where each wavelength is modulated at a frequency which depends upon the wavelength[7].

The aim of this work is to apply FT-IR PAS step scan mode to study penetration of substances into skin. 


\section{EXPERIMENTAL}

Abdominal pig skin, comprising stratum corneum and epidermis, $150 \mu \mathrm{m}$ thick, stored at $-20{ }^{\circ} \mathrm{C}$, was defrosted and dried for 1 hour. Dimethylsulfoxide(DMSO), a common vehicle used in topical drugs, was than applied either onto the surface or the bottom of the sample. The sample with DMSO was studied twice, the first experiment was carried out immediately after the sample preparation and the second being performed 24 hours after it was left in open air.

The experiment was performed by using a BioRad FTS-60 Spectrometer equipped with step scan mode and a MTEC 200 photoacoustic cell. Helium was used as carrier gas in the PA cell because of its superior thermal coupling properties. The spectrometer was purged with helium gas to remove atmospheric $\mathrm{H}_{2} \mathrm{O}$ and $\mathrm{CO}_{2}$. The frequency modulation used was $400 \mathrm{~Hz}$. The in-phase(I) and quadrature $(Q)$ interferograms were collected simultaneously and Fourier transformed after data collection was completed(off line). Having obtained I and $Q$, phase $(\theta=\mathrm{ATAN}(\mathrm{Q} / \mathrm{I}))$ and vector components of the spectra were calculated(7).

\section{RESULTS AND DISCUSSION}

Figure 1 shows the vector components at $135^{\circ}$ (where DMSO was easily observed) of: a) original skin; b) skin + DMSO applied into the surface; c) skin + DMSO applied on the bottom and d) skin + DMSO 24 hours later.

The absorption peaks around $2300 \mathrm{~cm}^{-1}$ are due to $\mathrm{CO}_{2}$ in the air. The absorption bands at 1650 $\mathrm{cm}^{-1}$ and $1540 \mathrm{~cm}^{-1}$ come from skin amide I and amide II respectively[1]. In curve b where DMSO is more concentrated in the sample surface, the structure of its absorption bands can be seen around 2900 $\mathrm{cm}^{-1}, 1350 \mathrm{~cm}^{-1}$ and $1000 \mathrm{~cm}^{-1}$. At $1000 \mathrm{~cm}^{-1}$, where the skin does not present significant absorption, DMSO was more evident. In curve $c$, although less intense, the same absorption bands can be observed.

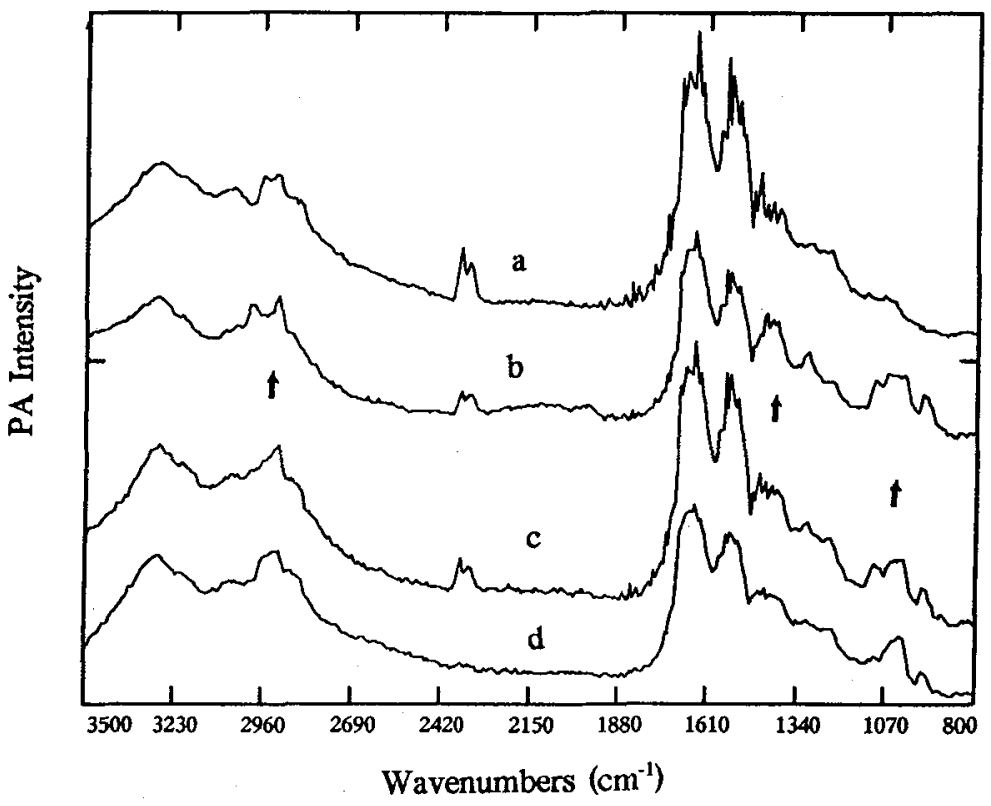

Figure 1. Step-scan FT-IR PA spectra at $400 \mathrm{~Hz}$ for vector components at $135^{\circ}$ :

a) original skin; b) skin + DMSO applied on surface; c) skin + DMSO applied on bottom; d) skin +DMSO 24 hours after application. 
For a heterogeneous sample such as skin, the theoretical detection for probed depth is $2 \pi \mu$ (approximately $6 \mu$ ). However, the practical signal-to-noise ratio in these FT-IR experiments makes the limit of detection to be around 2-3 $\mu \mathrm{m}[7]$. In a previous study, by using photoacoustic phase measurements, we determined the thermal diffusivity of this sample as $4.1 \times 10^{-4} \mathrm{~cm}^{2} \mathrm{~s}^{-1}$ [8]. Therefore, using the equation above, the thermal diffusion length is approximately $6 \mu \mathrm{m}$. Considering that our sample is $150 \mu \mathrm{m}$ thick, our data show that the probed depth is about $20 \mu \mathrm{m}$, indicating that DMSO propagated fast from the bottom through the skin, reaching its surface. In curve $d$, it can be observed that despite a much lower intensity, absorption bands from DMSO were still detected after 24 hours.

Figure 2 shows PA signal phase for samples a and b. At DMSO absorption band position the changes in phase induced by this substance can be seen.

In conclusion, by using FT-IR PAS Step Scan, we have shown the fast distribution of DMSO
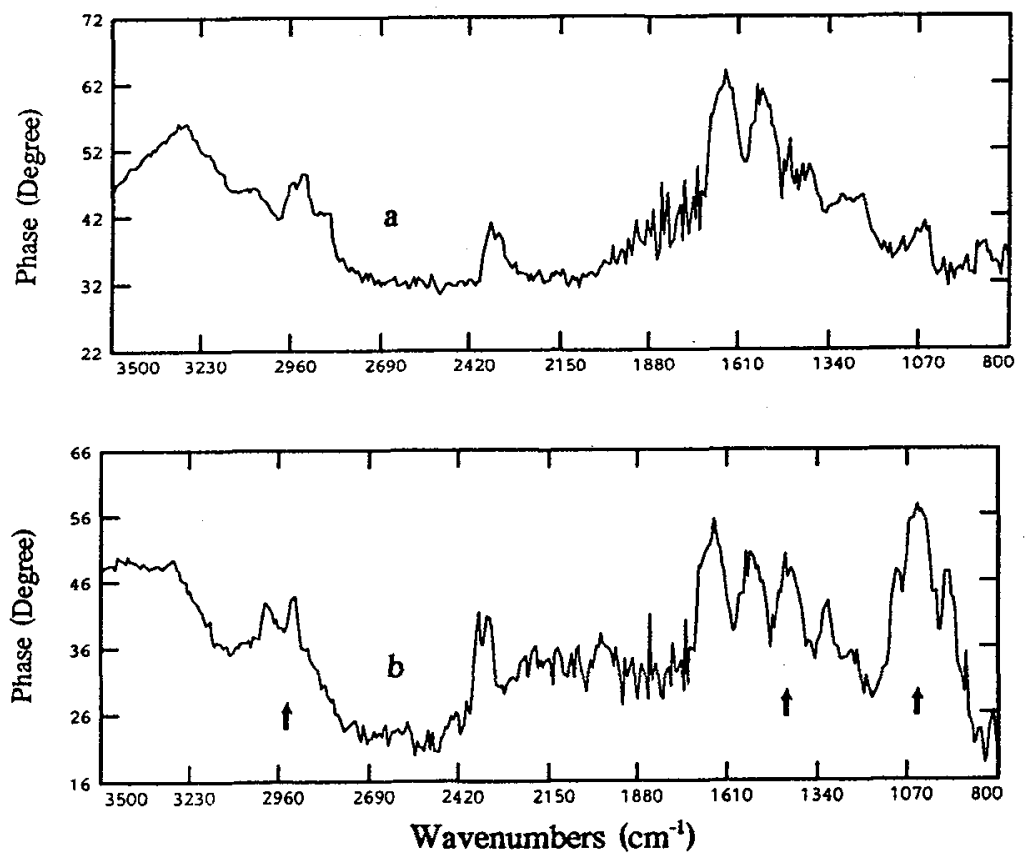

Figure 2. Photoacoustic signal phase of the samples $a$ and $b$.

through pig skin. Studies of penetration of sunscreen into skin, which is known to be slower[5] than that shown here for DMSO, are now being carried out.

\section{REFERENCES}

[1]. Klimisch,H.M. and Chandra,G., J.Soc.Cosm.Chem., 37,(1986), 73.

[2]. Scott,E.R., White,H.S. and Phipps, J.B.,Anal.Chem., 65,(1993), 1537.

[3]. Anjo,D.M. and Moore,T.A., Photochem. and Photobiol., 39,(1984),635.

[4]. Moore,T.A. Photochem. Photobiol. Rev., 7,(1983),187.

[5]. Giese,K., Nicolaus,A., Sennhenn,B. and Kolmel,K., Can.J.Phys., 64,(1986), 1139.

[6]. Baesso,M.L., Mansanares,A,M., Silva,E.C., Vargas,H. and Miranda,L.C.M., Phys.Rev.B, 40,(1989), 1880.

[7]. Palmer,R.A. and Dittmar,R.M., Thin Solids Films, 223,(1993),31.

[8]. Baesso,M.L., Shen,J. and Snook,R.D. Analyst, In Press, (1994). 